Siim Sultson

\title{
VIIVIKONNA - FORMATION OF \\ A GHOST TOWN AMONGST OTHER \\ EAST ESTONIAN OIL-SHALE MINING AND INDUSTRIAL TOWNS
}

\section{INTRODUCTION}

This paper focuses on the formation and renovation of East Estonian oil-shale mining and industrial town Viivikonna during the postwar Stalinist period (1946 to 1955) and post-Stalinist period (1966 to 1980). Aim of the paper is to analyse the formation processes and shed light on some aspects of the renovation of the ensemble-like town, that, in contrast to other East Estonian oil-shale mining and industrial towns Kohtla-Järve, Ahtme, Sompa, Jõhvi, Kukruse, Kiviõli, Kohtla-Nõmme and Sillamäe, though a brownfield, follows original urban planning pattern.

Wider historical and ideological background and formation mechanisms of East Estonian oil-shale mining and industrial towns Viivikonna, Kohtla-Järve, Ahtme, Sompa, Jõhvi, Kukruse, Kiviõli, Kohtla-Nõmme and Sillamäe are analysed in Siim Sultson's article "Formation Mechanisms of Stalinist Oil-Shale Mining and Industrial Towns in East Estonia: Soviet Nuclear Needs and Local Ambitions" $(2020)^{1}$, and more deeply, fundamentally and comprehensively, in his

DOI: https://doi.org/10.12697/BJAH.2020.19.06

1 Siim Sultson, "Formation mechanisms of Stalinist oil-shale mining and industrial towns in East Estonia: Soviet nuclear needs and local ambitions", Journal of Urban History, (2020), 1-22. See doi.org/10.1177/0096144219888506 [viewed 01.07.2020]. 
doctoral thesis "Stalinist Urban Ensembles in East Estonian Oil-Shale Mining and Industrial Town Centres: Formation Mechanisms and Urban Space Identity as the Potential for Spatial Development" (2019)².

The formation and structure of the population of East Estonian towns is analysed by historian David Vseviov in his doctoral thesis "Kirde-Eesti urbaanse anaomaalia kujunemine ning struktuur pärast teist maailmasõda" (The Formation and Structure of the Urban Anomaly in Northeast Estonia After the Second World War) ${ }^{3}$. Similar topic, in general, is explored in architectural historian Henry Kuningas" article "Hiilgava tuleviku poole. Stalinistlikud utoopialinnad põlevkivibasseinis" (To the Bright Future. Stalinist Utopian Towns in the Oil-Shale Basin).

This article neither argues for protection or demolition of Viivikonna nor takes a position on the future fate of the town. The article focuses above all on the settlement's formation (1946 to 1955) and renovation (1966 to 1980), that, in their turn, shaped the conditions for the different situation in Viivikonna compared to the other East Estonian oil-shale mining and industrial towns today. The formation and renovation are explored via original archival documents, many of which are used within the theme for the first time. The archival documents are quoted and analysed step by step in order to restore the processes that formed the urban space and structure of the town.

\section{ABANDONED TOWN AT A CROSSROADS}

On the one hand, as a legacy of the Soviet occupation, the existing oil-shale basin towns Kohtla-Järve, Ahtme, Sompa, Jõhvi, Kukruse, Kiviõli, Kohtla-Nõmme, Sillamäe and Viivikonna are regarded as something exotic and exciting, but on the other hand as a source of something strange and contradictory that led to the acute social

2 Siim Sultson, Stalinist Urban Ensembles in East Estonian Oil-Shale Mining and Industrial Town Centres: Formation Mechanisms and Urban Space Identity as the Potential for Spatial Development. Doctoral Thesis (Tallinn: TALTECH Press, 2019). See doi.org/10.23658 taltech.56/2019 [viewed 01.07.2020].

3 David Vseviov, Kirde-Eesti urbaanse anaomaalia kujunemine ning struktuur pärast teist the Second World Warm. Don and Structure of the Urban Anomaly in Northeast Estonia After

4 Henri Kuningas, "Hiilgava tuleviku poole. Stalinistlikud utoopialinnad põlevkivibasseinis" "To the Bright Future. Stalinist Utopian Towns in the Oil-Shale Basin"], Sõda ja sõjajärgne Narva linnamaastikus (Narva: Narva Muuseum, 2015), 245-261. problems including high unemployment. All these towns have underused spatial development potential, they are facing population shrinkage and decline in the planning of the region. However, in Kohtla-Järve, Ahtme, Sompa, Jõhvi, Kukruse, Kiviõli, KohtlaNõmme and Sillamäe, the Stalinist urban ensembles are protected by comprehensive plans and considered built-up areas of cultural and environmental value. Viivikonna is protected by neither of those to date. Before the Estonian administrative-territorial reform of local governments (2017), Viivikonna belonged to Kohtla-Järve agglomeration (since 1960) and was considered a city district. Since 2017 Viivikonna is subordinated to Narva-Jõesuu city and considered a village.

In "Sustainable Urban Area Development Strategy of Jõhvi and Kohtla-Järve 2015-2020", Viivikonna is mentioned five times as an area that should be dealt with", "Kohtla-Järve City Development Plan 2016-2034" statistically mentions Viivikonna as a city district ${ }^{6}$ and "Kohtla-Järve City Development Plan 2016-2034 Part I: Input Analysis" mentions Viivikonna four times as a statistical part of Kohtla-Järve7. But "Kohtla-Järve City Development Plan 2016-2034 Part II: Agenda" does not mention Viivikonna ${ }^{8}$. After the administrativeterritorial reform of local governments, Viivikonna is mentioned in "Narva-Jõesuu Development Plan up to 2025. Budget Strategy 2019-2022" as something that should be dealt with9. "Narva-Jõesuu Development Plan up to 2025. Budget Strategy 2019-2022: Agenda" mentions Viivikonna as something questionable that could be covered by some hypothetical actions (marked with question marks - S. S.) with hypothetical funding ${ }^{10}$. "Ida-Viru County Development Strategy

5 Jõhvi ja Kohtla-Järve linnapiirkonna jätkusuutliku arengu strateegia 2015-2020 [Sustainable Urban Area Development Strategy of Jõhvi and Kohtla-Järve 2015-2020] (Jõhvi, 2015), 6, Urb-31,65, 69 .

6 Kohtla-Järve linna arengukava 2016-2034 [Kohtla-Järve City Development Plan 2016 2034] (Kohtla-Järve, 2015), 5 .

7 Kohtla-Järve linna arengukava 2016-2034, I osa: lähteanalüüs [Kohtla-Järve City Development Plan 2016-2034, Part I: Input Analyses] (Kohtla-Järve, 2015), 25, 39-40.

8 Kohtla-Järve linna arengukava 2016-2034, II osa: tegevuskava [Kohtla-Järve City Development Plan 2016-2034, Part II: Agenda] (Kohtla-Järve, 2016).

9 Narva-Jõesuu arengukava kuni 2025. Eelarve strateegia 2019-2022 [Narva-Jõesuu Development Plan up to 2025. Budget Strategy 2019-2022] (Narva-Jõesuu; Sinimäe, 2018), 21.

10 Narva-Jõesuu arengukava kuni 2025. Eelarve strateegia 2019-2022: tegevuskava [NarvaJõesuu Development Plan up to 2025. Budget Strategy 2019-2022: Agenda] (Narva-Jõesuu Sinimäe, 2018), 8. 


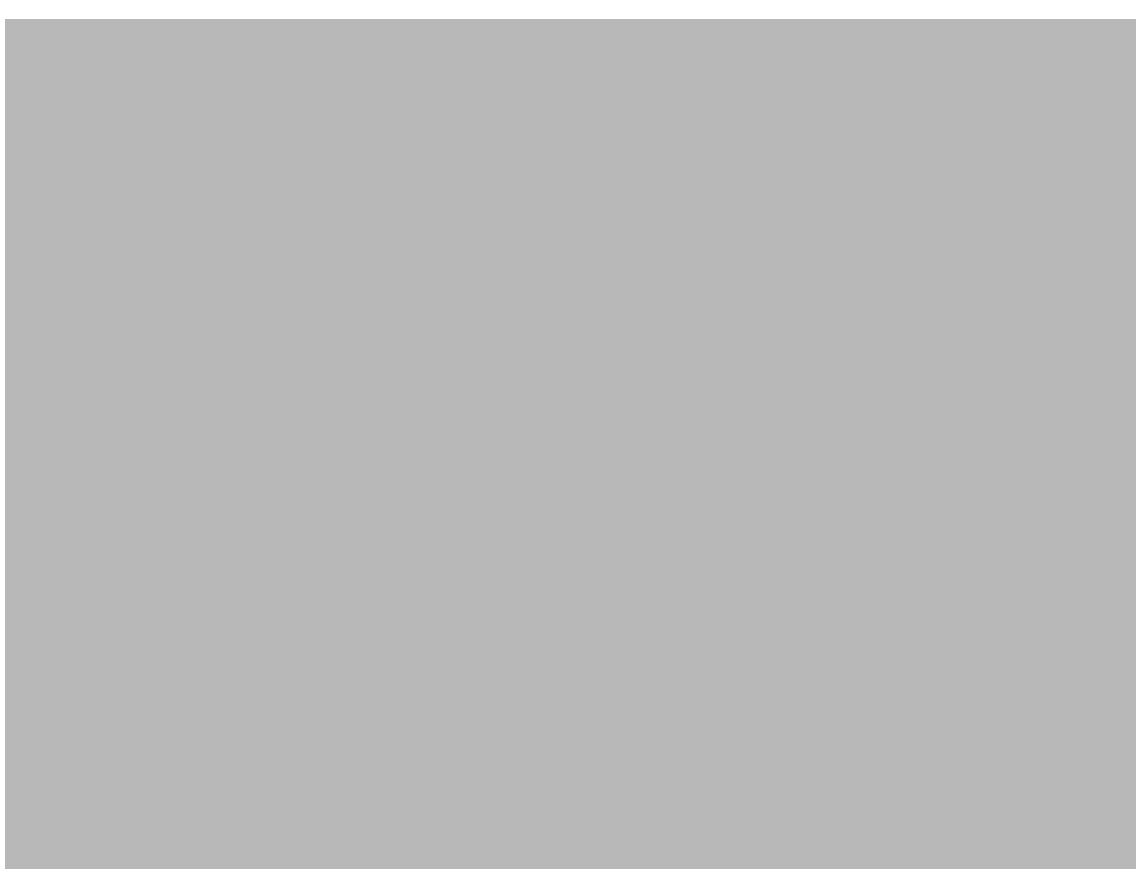

FIG. 1. MAIN STREET (RAHU STREET) OF VIIVIKONNA (EARLY 1950S) BY LENGIPROSHAKHT PHOTO: SIIM SULTSON (2018).

2019-2030+" just statistically mentions the existence of Viivikonna, and appendix 1 ("Agenda for Years 2019-2023", concerning certain funding from certain sources/budgets for several activities) for the same document mentions Viivikonna as a subject that could be covered by two hypothetical activities (compilation of a restructuring plan and/or establishment of a theme park) without any funding (funding fields have remained empty) ${ }^{11}$. Thus, Viivikonna is still not protected by comprehensive plans nor considered a built-up area of cultural and environmental value.

11 Ida-Viru maakonna arengustrateegia 2019-2030+ [Ida-Viru County Development Strategy 2019-2030+] (Ida-Viru maakond, 2018), 21; Ida-Viru maakonna arengustrateegia 2019-2030+ tegevuskava aastateks 2019-2023 [Ida-Viru County Development Strategy 2019-2030+: Agend for Years 2019-2023] (Ida-Viru maakond, 2018), 15, 34
However, due to the so-called position of outlaw, and hence poor maintenance, Viivikonna - the only East Estonian oil-shale mining and industrial town that follows urban planning principles and a pattern, established by the Department of Architecture of the Estonian SSR, led by Harald Arman, obviously faces demolition.

In order to make balanced and well-argued decisions on the fate of Viivikonna, it is crucial to know the reasons and processes for establishing that town - what was the background.

\section{FORMATION PERIOD (1946 TO 1955)}

During the seizure of Estonia $(1940,1944)$ by the Soviet Union, the new regime considered East Estonia a resource for oil-shale: the oil-shale deposits that were suitable for heating and producing electricity, oilshale gas, shale oil, oil-shale gasoline, oil-shale based uranium ore, et cetera. Between two Soviet occupations, in 1941 to 1944, Germany was interested in East Estonian oil-shale as well.

As Olaf Mertelsmann states, before the Second World War, in spring 1941, the Soviet Union intended to increase the annual total of mining of East Estonian oil-shale up to 8 million tons by 1945, which would have increased the previous amount over four times within five years, and it would have been nearly $80 \%$ of the whole state's capacity ${ }^{12}$. After the Second World War, the Soviet state was in utter need for the oil-shale deposits. On 15 June 1945, the USSR's People's Commissar of Coal Industry Vasiliy Vakhrushev passed a governmental command that was followed by a five-year plan (1945 to 1950), which was passed by the USSR's State Defence Committee nearly a month later, on 10 July 1945. Both documents concerned the reconstruction and rehabilitation of East Estonian oil-shale industry and settlements. According to both of them, the annual total mining of oil-shale had to rise from 1.9 million tons in 1945 to 7.8 million tons by 1948 (i.e. a fourfold increase over four years), and to 8.4 million tons by 1950 . However, the first attempts to organise East Estonian oil-shale area took place in 1947. On 20 July 1947, the Estonian SSR's Council of Ministers passed a directive "About the Organisation of Project-Planning Works for the Oil-Shale

12 Olaf Mertelsmann, "Ida-Virumaale sisserändamise põhjused pärast teist maailmasõda" ["The Reasons for Immigrating to Ida-Virumaa Region After the Second World War"], Ajalooline Ajakiri, 1 (119) (2007), 53-4. 
Region". According to the directive, the Department of Architecture of the Estonian SSR compiled a document "Technical-Economic Principles for the Development of the Estonian SSR's Region Where Oil-Shale Occurs". The document was followed by a large-scale secret project "Planning Task for Industrial and Urban Development of the Estonian SSR's Region Where Oil-Shale Occurs", compiled by the same department with its Planning and Design Office, the design institute "Estonproyekt" in 1948-1950 (as a secret project printed in 1951). The secret project seeks economic efficiency and high productivity for the East Estonian oil-shale territory with an area of $4000 \mathrm{~km}^{2}(100 \mathrm{~km}$ from Rakvere to Narva, and $40 \mathrm{~km}$ south from the Gulf of Finland) from 1948 to 1970. The territory contains oil-shale towns (e.g. KohtlaJärve, Jõhvi, Ahtme, Kiviõli) and smaller settlements (e.g. Sompa, Viivikonna, Kukruse). The annual total mining of oil-shale had to rise from 3 million tons in 1948 (actual annual total of mining) up to 25 million tons by $1970 . .^{13}$

On 13 September 1946, following a governmental order of the USSR's Ministry of Coal Industry for the Western Regions, passed on 28 August 1946, the Department of Oil-Shale Industry's Combine "Estonslanets", the local branch of the same ministry, passed a command concerning the reconstruction and rehabilitation of Viivikonna. According to the command, all reconstruction and rehabilitation works in the town had to be accelerated and completed within a year in order to fulfil the five-year plan. ${ }^{14}$. The southeastern rectangular grid is visible in the 1940-1943 master plan for Viivikonna ${ }^{15}$. Architect Anton Soans made a design for workers' twostoreyed apartment buildings in March $1941^{16}$. The same grid was in use after the Second World War, while the simple one-storeyed houses and barracks were erected. The grid with northern east-west, southern east-west and three north-south streets defines the older part of Viivikonna ${ }^{17}$.

13 Sultson, Stalinist Urban Ensembles in East Estonian, 85-6, 89-95; Sultson, "Formation mechanisms of Stalinist", 7-9.

14 National Archives of Estonia [Rahvusarhiiv], RA, ERA.R-972.1.84, 1-4

15 RA, ERA.T-8.1.111, 5-6; RA, ERA.T-8.1.101

16 RA, ERA.T-8.1.111, 1-4.

17 RA, ERA.T-8.1.111, 5-6; RA, ERA.T-8.1.101; RA, ERA.R-3.3.1301, 3.

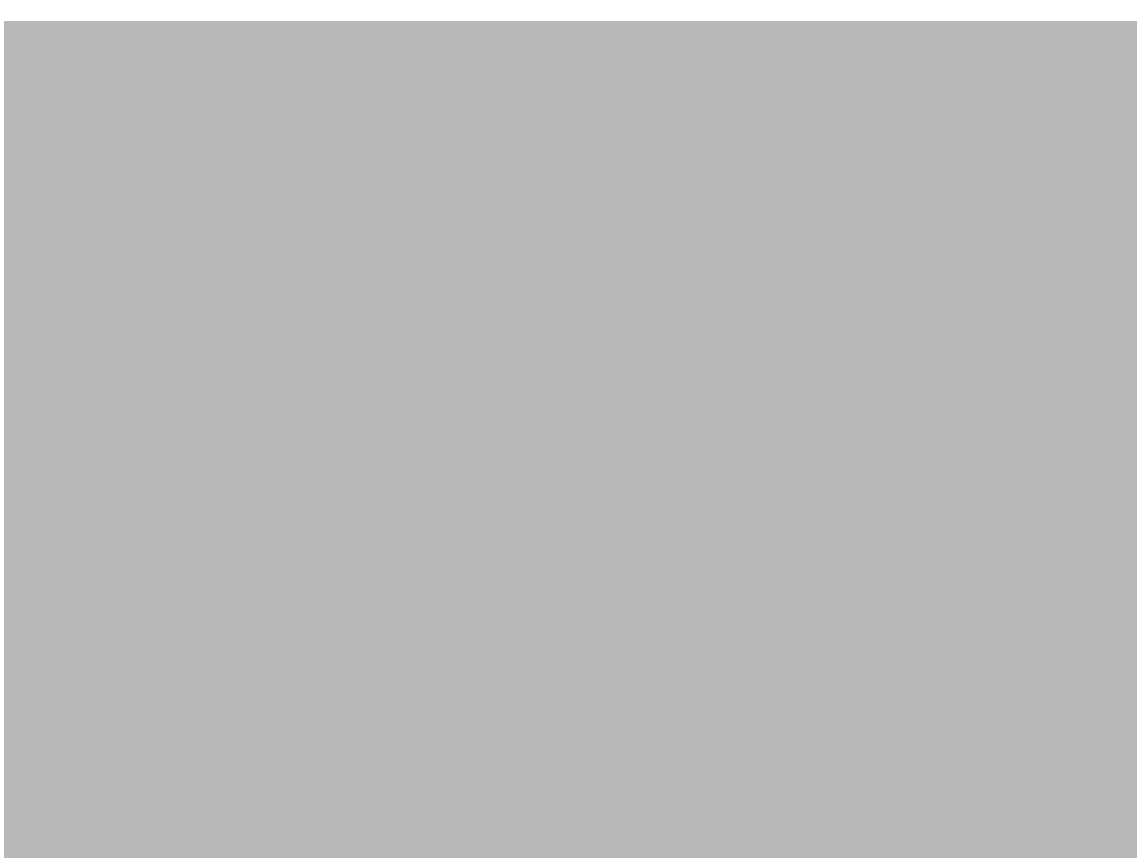

FIG. 2. MASTER PLAN OF VIIVIKONNA (1949) BY LENGIPROSHAKHT. ON THE RIGHT: THE MOSTLY BUILT PART OF THE TOWN. ON THE LEFT: THE MOSTLY UNBUILT PART OF THE MAIN STREETS. RA, ERA.R-3.3.3148, 18

Viivikonna was designed by Lengiproshakht ${ }^{18}$ already in Autumn $1947^{19}$. According to the 1949 (December) master plan, Lengiproshakht laid out Viivikonna using regular and straightforward grids, and organised the town using orthogonal geometry. Stately urban ensemble as centre of Viivikonna was supposed to consist of four crossing axes. The eastern east-west one, the main street, had to be nearly 25 metres wide and 300 meters long, continued with a central square (66 meters long, 55 meters wide) with a stately local government building and stately two-storeyed apartment buildings. The central square, in its turn, had to be linked to shifted western east-west axe (210 meters

18 Leningrad branch of all-Soviet Union Giproshacht (State Institute for Planning Mines under the USSR's People's Commissariat of Coal Industry).

19 RA, ERA.R-1992.3.3, 22 
long, 25 meters wide) as a prolongation of the main street. The latter had to connect the central square with the Palace of Culture within a park. The central square had to be crossed by eastern north-south axe (340 meters long, 20 meters wide). The junction of the greenery and the western east-west axe had to be crossed by a western northsouth axe (340 meters long, 20 meters wide). The eastern east-west axe had to be flanked by two-storeyed stately apartment buildings and a school building. The western east-west axe had to be flanked by twostoreyed stately apartment buildings and two kindergartens. Central parts of both north-south axes had to be flanked by two-storeyed stately apartment buildings. The southern east-west boulevard (680 meters long, 20 meters wide) had to be flanked by a polyclinic, onestoreyed and two-storeyed houses, and to connect railroad territory and the southern part of the town with its western area (simple onestoreyed, semi-detached residential houses). ${ }^{20}$ However, in Viivikonna, just half of the master plan (1949) was implemented.

Both in 1948 and 1949, the master plan was analysed in the Department of Architecture of the Estonian SSR. The department suggested correcting the master plan: for instance, owing to swampy soil and costs of infrastructural works, to prefer two-storeyed housing stock instead of the lower one, and decrease the town's territory survey from 1 November $1949^{21}$. The latter version from December 1949 was accepted on 12 January 1950. The acceptance was followed by a reference draft of a directive "About Authorization of the Master Plan and the Detailed Plan of First-Order Construction of Viivikonna Settlement" sent to the Estonian SSR's Council of Ministers by the Department of Architecture of the Estonian SSR. ${ }^{22}$

On 8 March 1950, H. Arman asked the Vice-Chairman of the Estonian SSR's Council of Ministers Konstantin Boitsov permission to start the building of two blocks of the detailed plan of first-order construction, while the whole master plan was sent to be authorized by the Estonian SSR's GOSPLAN ${ }^{23}$ and to suggest the Estonian SSR's GOSPLAN to accelerate the examination of the master plan. The

20 RA, ERA.R-3.3.3148, 18

21 RA, ERA.R-1992. 2.63, 240

22 RA, ERA.R-1992.2.44, 109-146.

23 The Estonian SSR's State Planning Committee, local branch of the GOSPLAN (the USSR's State Planning Committee).
Vice-Chairman gave the permission on 14 March 1950. However, on 27 March 1950, a session of the Estonian SSR's GOSPLAN deemed the master plan and the detailed plan of first-order construction inadequate since the town was planned on "the very marshland" with drainage for 25 million roubles and without any preliminary analyses. The Estonian SSR's GOSPLAN rejected the master plan and the detailed plan of first-order construction of Viivikonna and proposed to choose another, drier territory for the town Meanwhile, the territory of Viivikonna was already in use. Though representatives of the Department of Architecture of the Estonian SSR (engineers Arnold Taremäe and Vsevolod Tikhomirov) were present in the session, on 7 April 1950 the Vice-Chairman of the department Voldemar Meigas, in his letter to the Vice-Chairman of the Estonian SSR's Council of Ministers, after explaining the choice of the current territory for Viivikonna, ${ }^{24}$ including the possibility to intensify housing by increasing the number of storeys, asked the Estonian SSR's Council of Ministers to evaluate the master plan and the detailed plan of first-order construction, once more. ${ }^{25}$

What was the reason for such a result? On 21 to 26 March 1950, the 8th plenum of the Central Committee of the Communist Party of Estonia took place. As historian Olev Liivik writes, in 1950, after the plenum an extensive purge of personnel occurred in the republic's power structures. As a result, local Estonians, placed in local soviet power structures in the 1940s were dismissed from their positions. For instance, members of the Council of Ministers were dismissed mostly due to political motives in connection with the "Estonian Affair" initiated in Moscow. ${ }^{26}$

As a result of the plenum, political atmosphere very quickly changed in Estonia. Fearing dismissal and, in some cases, repression, every official of the republic's power structures (the Estonian SSR's Council of Ministers, the Estonian SSR's GOSPLAN included) demonstrated political vigilance and eagerness. Rejection of the master plan and the

24 As V. Meigas describes, in February 1947, the first territory was chosen 2 to 2.5 kilometres to the north-east of the existing territory, but two months later, the existing territory was preferred. Though both territories had thick peat strata, the existing one had better condition for drainage works.

25 RA, ERA.R-1992.2.44, 102-108; RA, ERA.R-1992.2.63, 219-220, 223.

26 Olev Liivik, Eesti NSV Ministrite Nõukogu institutsionaalne areng ja kaadrid 1940-1953 Institutional development and the cadres of the council of Ministers of the Estonian SSR, 19401953]. Doctoral Dissertation (Tartu: Tartu Ülikool, 2014), 151, 164-8, 187, 205, 245, 246, 251-2. 
detailed plan of first-order construction of Viivikonna by the Estonian SSR's GOSPLAN, and the institution's suggestion to choose another territory for the town had to demonstrate vigilance against waste of the state's finances. As V. Meigas stated, transferring Viivikonna from its current ("On 15 April 1947...already containing existing living area of 5,000 $\mathrm{m}^{2} . .$. ") site near the oil-shale mine and, as a result, transportation of the mine workers from a remote town to the mine in the future could be hard to realise, i.e. expensive ${ }^{27}$.

Reaction to V. Meigas' letter came from the Vice-Chairman of the Estonian SSR's Council of Ministers on 11 September 1950, i.e. in five months (- the addressee of 7 April 1950 was removed for deployment to the Communist Party of the Soviet Union 12 days later $\left.{ }^{28}\right)$. In the letter, the Estonian SSR's Council of Ministers gave permission to develop Viivikonna on its current site, taking into account only the needs of the existing mine, greatly reducing the territory, intensifying population by increasing the number of storeys (up to three storeys in the town centre and two to three storeys in main streets), and decreasing the percentage of one-storeyed houses to $15 \% .^{29}$

As stated by the Department of Oil-Shale Industry's Combine "Estonslanets" on 23 June 1951, the Department of Architecture of the Estonian SSR accepted the master plan of Viivikonna with some remarks on 21 February 1951; however, on 2 July 1951, experts of the Department of Architecture of the Estonian SSR commented that neither the condition to increase the number of storeys up to three nor the condition to decrease the percentage of one-storeyed houses to $15 \%$ were not followed ${ }^{30}$.

On 5 July 1951, the Expertise Bureau of the Department of Architecture of the Estonian SSR in conclusion of their survey stated that due to the reduction of the town's territory, where the area of thick peat strata has been excluded, the cost of technical preparation of the territory has been reduced by six to eight times. "According to the technical-economic account [the 1949 staff working documents for the official 1951 secret project and the official 1951 secret project itself - S. S.], the population [of Viivikonna - S. S.] is determined to 2,700

27 RA, ERA.R-1992.2.44, 102,103.

28 Liivik, Eesti NSV Ministrite Nõukogu institutsionaalne, 272, 281.

29 RA, ERA.R-1992.2.63, 223-224.

30 RA, ERA.R-1992.2.63, 224-225, 236. people by the first-order period [in $1955-$ S. S. ${ }^{31}$ and to 2,500 people by the estimated period [in 1970 - S. S.]. Development for the settlement [Viivikonna - S. S.] is not stipulated," declares the conclusion. But the same conclusion propounds that "according to the project of regional planning of the oil-shale basin [the official 1951 secret project - S. S.], developed by the Department of Architecture of the Estonian SSR, the settlement [Viivikonna - S. S.] has perspectives of development; moreover, the territorial enlargement of the housing stock on the current territory is possible.". ${ }^{32}$ The conclusion is contradictory.

Furthermore, the Department of Architecture of the Estonian SSR, neglecting to mention not following neither condition of the Estonian SSR's Council of Ministers, suggested the master plan and the detailed plan of first-order construction of Viivikonna for acceptance after correction of some technical and formal details. The department designed a reference draft of a directive on authorization of the master plan, taking into account the remarks of the Department of Architecture of the Estonian SSR, and sent it to the Estonian SSR's Council of Ministers already on 6 July 1950. The Estonian SSR's Council of Ministers authorized the master plan on the next day. ${ }^{33}$

The Expertise Bureau of the Department of Architecture of the Estonian SSR analysed the designs for the 3rd block (October to November 1951) and 4th block (July to August 1952) of Viivikonna. Neither the conclusion concerning the 3rd block nor the conclusion concerning the 4th block mentioned anything on the necessity for three-storeyed housing stock (though, one expert found the density of living area per one hectare too low: lower than stipulated in building standards). ${ }^{34}$

Even though, as stated above, the current territory of Viivikonna was referred to as "the very marshland" (the Estonian SSR's GOSPLAN), and having thick peat strata, and being swampy (the Department of Architecture of the Estonian SSR), similarly to V. Meigas' letter ${ }^{35}$, experts of the Department of Architecture of the Estonian SSR indicated the possibility to build the houses with basements ${ }^{36}$.

\footnotetext{
31 RA, ERA R-1527.2.44, 48.

32 RA, ERA.R-1992.2.63, 220.

33 RA, ERA.R-1992.2.63, 216-220; RA, ERA.R-1992.2.76, 101.

34 RA, ERA.R-1992.2.63, 244-246; RA, ERA.R-1992.2.76, 101-105.

357 April 1950: the existing territory had better conditions for drainage works.

36 RA, ERA.R-1992.2.63, 225
} 
Consequently, technically, it was possible to build on the current territory. But it is likely that the use of the land for oil-shale mining was an issue.

\section{DEEPER CIRCUMSTANCES AND REASONS. DISCUSSION}

In the 1949 staff working documents for the official 1951 secret project, while the Department of Architecture of the Estonian SSR proposed intensified housing for economic efficiency, in order to save the surrounding territory for oil-shale mining ("maximum decrease of unproductive oil-shale deposits"), the USSR's State Committee of Architecture at the USSR's Council of Ministers via its experts (in April, May and December 1949) and the institution itself (in June 1949) advised the Department of Architecture of the Estonian SSR to increase the density of population in all of the East Estonian oilshale territory with an area of $4000 \mathrm{~km}^{2}$. Still, the experts, apropos the building and population of any town, suggested consulting with the Mining Engineering Inspection of the USSR's Ministry of Coal Industry. For instance, as the First Department of the State Mining Oversight at the USSR's Council of Ministers stated in its letter to the USSR's State Committee of Architecture, while the placement of settlements or industrial plants inevitably causes abandonment of some part of oil-shale deposits, building of any settlement or industrial plant in the Estonian region where oil-shale occurs required the institution's permission. The USSR's State Committee of Architecture supplemented the crucial demand to save territory for oil-shale mining with the need for well-equipped (i.e. functional and stately) urban space. As a result, in the official 1951 secret project to increase the economic efficiency and high productivity of the oil-shale area, the Department of Architecture of the Estonian SSR proposed to intensify the housing by increasing the number of storeys for houses (residential etc). Such a proposal aimed to decrease the territory under the settlements from 5,000 ha to 3,300 ha, which meant 1,700 ha extra for the oil-shale mining, while increasing the overall population on the territory with the area of $4000 \mathrm{~km}^{2}$ by $1970 .{ }^{37}$

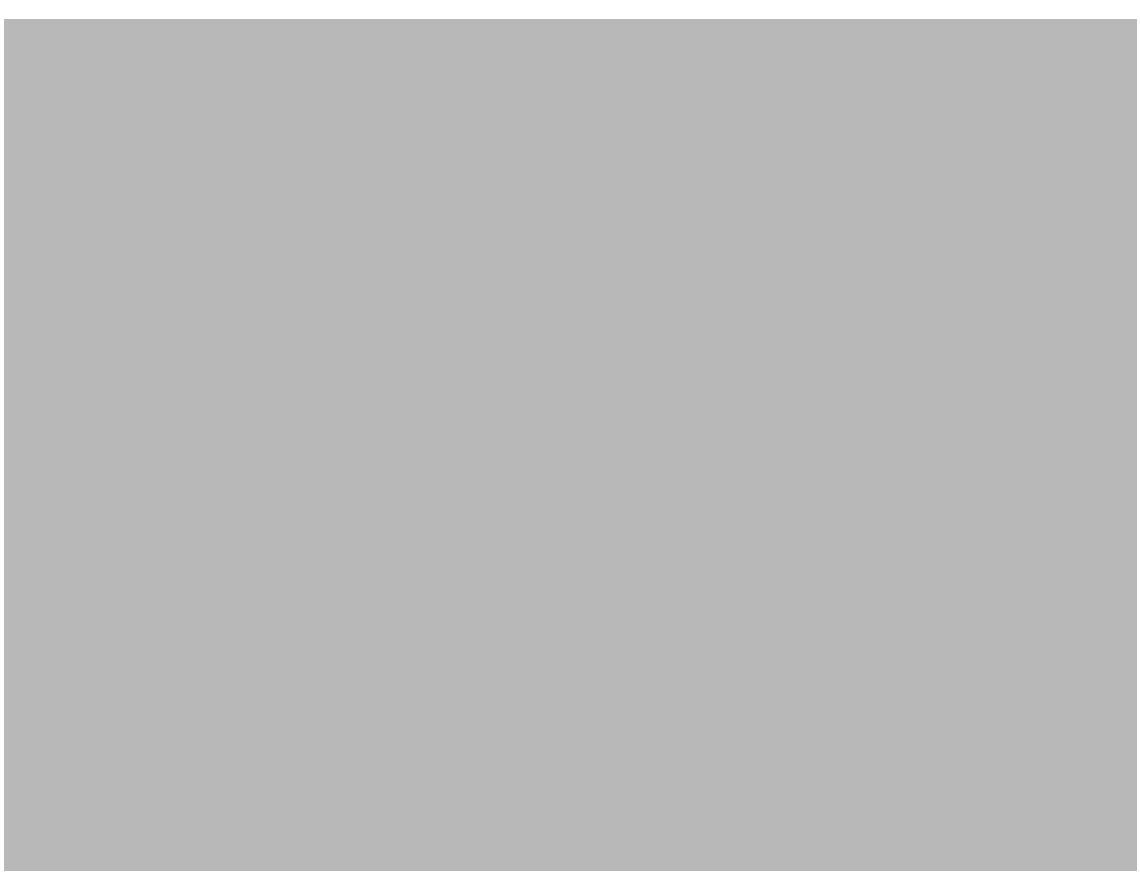

FIG. 3. PLANNING TASK FOR INDUSTRIAL AND URBAN DEVELOPMENT OF THE ESTONIAN SSR'S REGION WHERE OIL-SHALE OCCURS BY THE DEPARTMENT OF ARCHITECTURE OF VIIVIKONNA. A BIT LOWER: NEW TOWN VALGE-JÄRVE. TOP CENTRE: SOMPA, KOHTLA KOHTLA-JÄRVE, KUKRUSE, JÕHVI, AHTME. LEFT: KIVIÕLI, CENTRE: NEW TOWN ILLUKA. RA, ERA.R-1527.2.44, SHEET 9.

Probably because of the above-mentioned aspects, in Viivikonna only half of the master plan was implemented. Similarly, in Ahtme $1 / 3$, in Sompa and Kiviõli $1 / 4$ of the master plan were realised, while the building of new town Kohtla was cancelled. For instance, the 1951 official secret project indicates the decrease in the population of Sompa, from 15,000 people to 9,000 people, while one- and twostoreyed houses were replaced with two- to three-storeyed houses: that caused a withdrawal of $3 / 4$ of the master plan. ${ }^{38}$

38 Sultson, "Formation mechanisms of Stalinist", 12-3; Sultson, Stalinist Urban Ensembles in East Estonian, 93-4, 98-100. 
Viivikonna's population figures are rather contradictory during the formation period. The 1951 official secret project (compiled in 1948 to 1950) gives 700 people as the existing estimate of Viivikonna's population (in 1948, i.e. on 1 October 1948), 4,700 as a number by the first-order period (in 1955), and 5,500 by the estimated period (in 1970) ${ }^{39}$. Conclusion of the Expertise Bureau of the Department of Architecture of the Estonian SSR, passed on 5 July 1951, mentions the population as 2,700 people by the first-order period (in 1955), and 2,500 people by the estimated period (in 1970) ${ }^{40}$.

On 19 December 1949, Jõhvimaa Rural Municipality Executive Committee asked the Estonian SSR's Supreme Soviet to form Viivikonna as a workers' settlement with its own local municipality. The same document sates that Viivikonna is a settlement with existing living area of 7,305 $\mathrm{m}^{2}, 69$ residential houses, five shops, a canteen, a school for 146 pupils and a kindergarten for 50 children, a club for 200 visitors, and with the population of 3,000 people ${ }^{41}$. Meanwhile, the 1951 official secret project depicts Viivikonna as a settlement with existing living area of $3,800 \mathrm{~m}^{242}$ and a population of 700 people in $1948^{43}$. On 7 April 1950 V. Meigas describes Viivikonna as a settlement that, on 15 April 1947, already contained existing living area of 5,000 $\mathrm{m}^{244}$. Jõhvimaa Rural Municipality Executive Committee predicted the population of the settlement to reach 3,500 people by $1951,4,000$ by $1952,4,000$ [that is not a mistake - S. S.] by $1953,4,259$ by 1954 and 4,500 by 1955 . The Estonian SSR's Supreme Soviet authorized the request on 13 May $1950 .{ }^{45}$

On 2 to 3 July 1951 (just prior to the conclusion by the Expertise Bureau of the Department of Architecture of the Estonian SSR), the survey of the detailed plan of first-order construction of Viivikonna, in its comment on the population of the town, mentions that since

39 RA, ERA.R-1527.2.44, 35, 36, sheet 9.

40 RA, ERA.R-1992.2.63, 220.

41 RA, ERA.R-3.3.1301, 2.

42 The 1951 official secret project adds to figure $3,800 \mathrm{~m}^{2}$ (residential houses) figure $(3,800$ $\mathrm{m}^{2}$ (barracks) - that is equal to $7,600 \mathrm{~m}^{2}$. The 1951 official secret project states, that exposed
figure of population for 1948 may not reflect actual figure of population, for example, due to excluding figure of "spetzkontingent" (special category - convicts)

43 RA, ERA.R-1527.2.44, 36, 39, sheet 9 .

44 RA, ERA.R-1992.2.44, 102,103.

45 RA, ERA.R-3.3.1301, 2, 7, 9

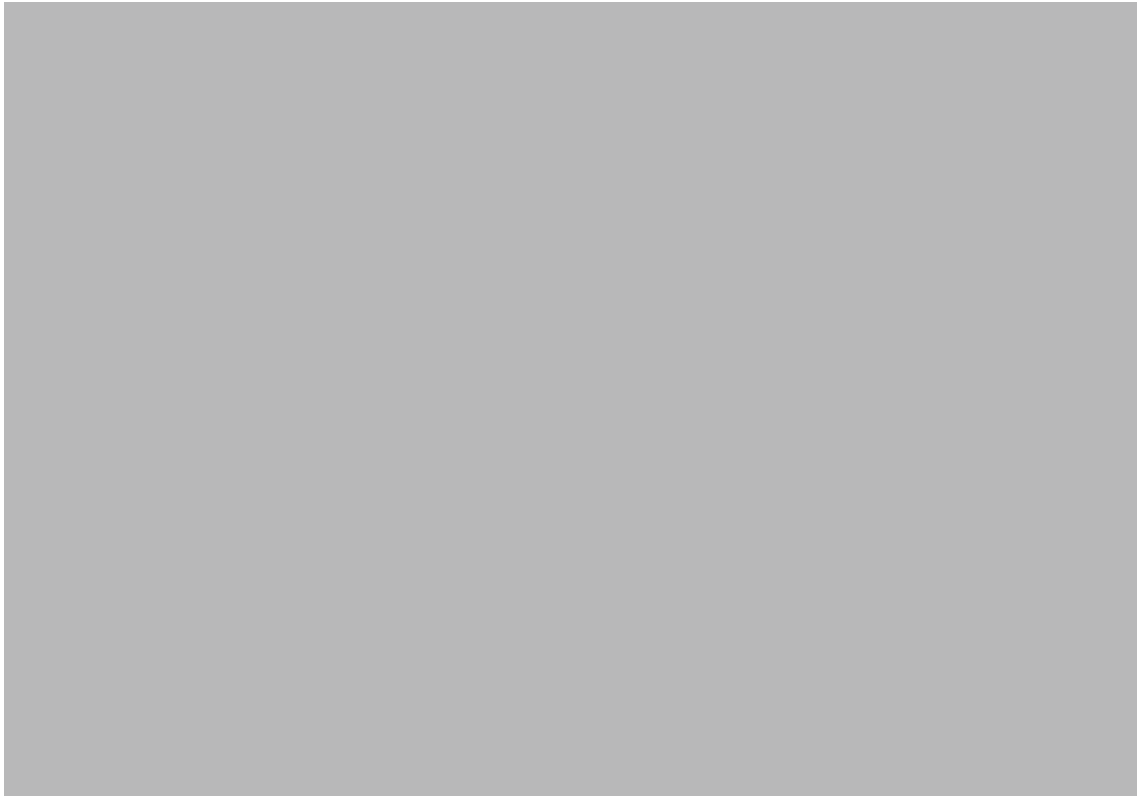

FIG. 4. VIIVIKONNA (EARLY 1950S) BY LENGIPROSHAKHT. LEFT: WATER TOWER. BACKGROUND HOUSING STOCK OF THE TOWN. PHOTO: VIRUMAA MUSEUMS [VIRUMAA MUUSEUMID] VM, RM F 186.6.

according to the project of the region where oil-shale occurs [the official 1951 secret project - S. S.] Viivikonna would be subjected to further development by increasing the population approximately twofold, it is possible to agree with the population figure proposed in the detailed plan of first-order construction ${ }^{46}$.

For instance, on 28 July 1957 Jõhvi District Executive Committee in its request (addressed to the Estonian SSR's Supreme Soviet), concerning the authorization of Viivikonna's borders, describes the town as a settlement with existing living area of $12,247 \mathrm{~m}^{2}, 75$ residential houses, a secondary school, a kindergarten, a nursery, a club with cinema facilities, a canteen, two bathhouses, workshops for cobbler, photographer and hairdresser, and with a population of 1,823 people $^{47}$.

46 RA, ERA.R-1992.2.63, 230

47 RA, ERA.R-3.3.3148, 9, 16. 
If we compare the proposed living area figures for $1947\left(5,000 \mathrm{~m}^{2}\right)$ $1948\left(3,800 \mathrm{~m}^{2}\right), 1949\left(7,305 \mathrm{~m}^{2}\right)$, and $1957\left(12,247 \mathrm{~m}^{2}\right)$, then based on the 1951 official secret project (see footnote 50 ) it seems reasonable to use the figure of 7,600 $\mathrm{m}^{2}$ for 1948. For example, in October 1949, secretary of the local party organisation of Viivikonna, in an extract of the organisation's meeting concerning renaming of existing streets of the town, mentions Finnish cabins (i.e. barracks) ${ }^{48}$. It is possible that the living area figures for 1947 and 1949 include barracks. Considering the modest increase in residential houses - from 69 in 1949 to 75 in 1957 (i.e. six residential houses in eight years) - the 1957 living area figure could contain barracks, as well. Additionally, if we compare the proposed population figures for 1948 (700 people), 1949 (3,000 people), and 1957 (1,823 people), there seems to be contradiction and illogicality in those figures.

As stated in the Soviet Architect's Handbook of 1946, during the first-order construction (period of five years) ${ }^{49}$ of a settlement, living area per one inhabitant could be $6 \mathrm{~m}^{2}$ (equal to coefficient 1.5) instead of common standard $9 \mathrm{~m} 2$ (equal to coefficient 1.0); the smallest figure could be $4 \mathrm{~m}^{2}$ (equal to coefficient 2.2) ) $^{50}$.

Thus, based on standard $6 \mathrm{~m}^{2}$ per one inhabitant, the population of Viivikonna could be calculated as follows: 833 people in 1947, 1,266 (without barracks 633) people in 1948, 1,218 people in 1949, and 2,041 people in 1957. In case of 1957, because of the post-first-order construction period, at least partial ( $1 / 2)$ use of the common standard $9 \mathrm{~m}^{2}$ per inhabitant helps to decrease the population figure to 1,701 people. Since shortage of living area was common in the Soviet Union, the figures, derived by calculation, could be rounded up to the nearest hundred as follows: 900 people in 1947, 1,300 (without barracks 700) people in 1948, 1,300 people in 1949 and 1,800 people in 1957. The figures for 1948 match precisely. For example, if we add thirty people to the derived and rounded figures, the result matches the figure for 1957 quite well; the same could be probable for years 1947 and 1949. Consequently, the population of 3,000 people, mentioned on 19 December 1949, was exaggerated approximately twofold.

48 RA, ERA.R-3.3.1301, 3.

49 The 1951 official secret project suggests the period up to 1955.

50 Kratkii spravochnik arhitektora [Short Regulations for the Architect]. (Moscow: Gosudarstvennoe izdatel'stvo literatury po stroitel'stvu i arhitektureKratkii spravochnik arhitektora, 1946), 57
Meanwhile, the 1951 official secret project states that because of swamps the eastern part of the oil-shale area is poorly inhabited. Viivikonna as a settlement under construction is maintained for the Viivikonna mine, mine number $23^{51}$. The five other southern mines $(24,25,26,28,29)$ were intended to be served by the new town of Valge-Järve with the population of 20,000 people (in 1970) ${ }^{52}$. The project refers to necessary melioration works on the eastern part of the oil-shale area. Very flat descent of the strata [e.g. oil-shale - S. S.] from the ground surface into the depths, as the project states, provides an opportunity to establish surface mines as a lane zone five kilometres wide and 15 to 20 meters deep. Practical absence of arable lands and insignificant quantity of settlements would contribute to the establishment of such mines. ${ }^{53,54}$

Via derivation by calculation, based on the suggested average needs for schools, kindergartens, nurseries, polyclinics, clubs, bathhouses, bakeries, mentioned in the Soviet Architect's Handbook of 1946 and its 4th extended edition the Soviet Architect's Handbook of 1952 the master plan's projected population should be about 4,000 to $4,500 / 5,000$ people. The estimated figures coincide with figures shown on the map of the 1951 official secret project, ${ }^{55}$ and in the request by Jõhvimaa Rural Municipality Executive Committee (concerning years 1954, 1955). ${ }^{56}$ That matches the above-mentioned survey of 2 to 3 July 1951 and the conclusion of the Expertise Bureau of the Department of Architecture of the Estonian SSR, passed on 5 July 1951 - both documents, inter alia, consider the population of Viivikonna.

51 On the map, it seems that figures of mines for Viivikonna (mine number 23) and of new town Illuka (in 1970) (mine number 20) have got switched and figure of mine number 28 is printed twice, while number of mine 26 is missing; RA, ERA.R-1527.2.44, sheet 9 .

52 On the map, figure of population of Valge-Järve is 24,000 people; RA, ERA.R-1527.2.44 sheet 9 .

53 RA, ERA.R-1527.2.44, 47, 50

54 In addition to the main version, the 1951 official secret project has additional (parallel) version (for further development) that, for example, due to absence of new town Valge-Järve an union of eastern towns Aidu and new town Idalinn into one new town Kreksi, enables further development for Viivikonna. The 1951 official secret project reflects principles and decision as of autumn 1950; RA, ERA.R-1527.2.44, 48-50, sheet 8; RA, ERA.R-1992.3.12, 15-7.

55 Figures for Viivikonna are as from the period before the decision to decrease territory of the town.

56 Kratkii spravochnik arhitektora (1946), 53-56; Kratkii spravochnik arhitektora [Short Regulations for the Architect]. (Moscow. Gosudarstvennoe izdatel'stvo literatury po stroitel'stvu iarhitektuure, 1952), 10-2, 129-30, 190; RA, ERA.R-1527.2.44, sheet 9; RA, ERA.R-3.3.3148, 18; RA, ERA.R-3.3.1301, 2 . 


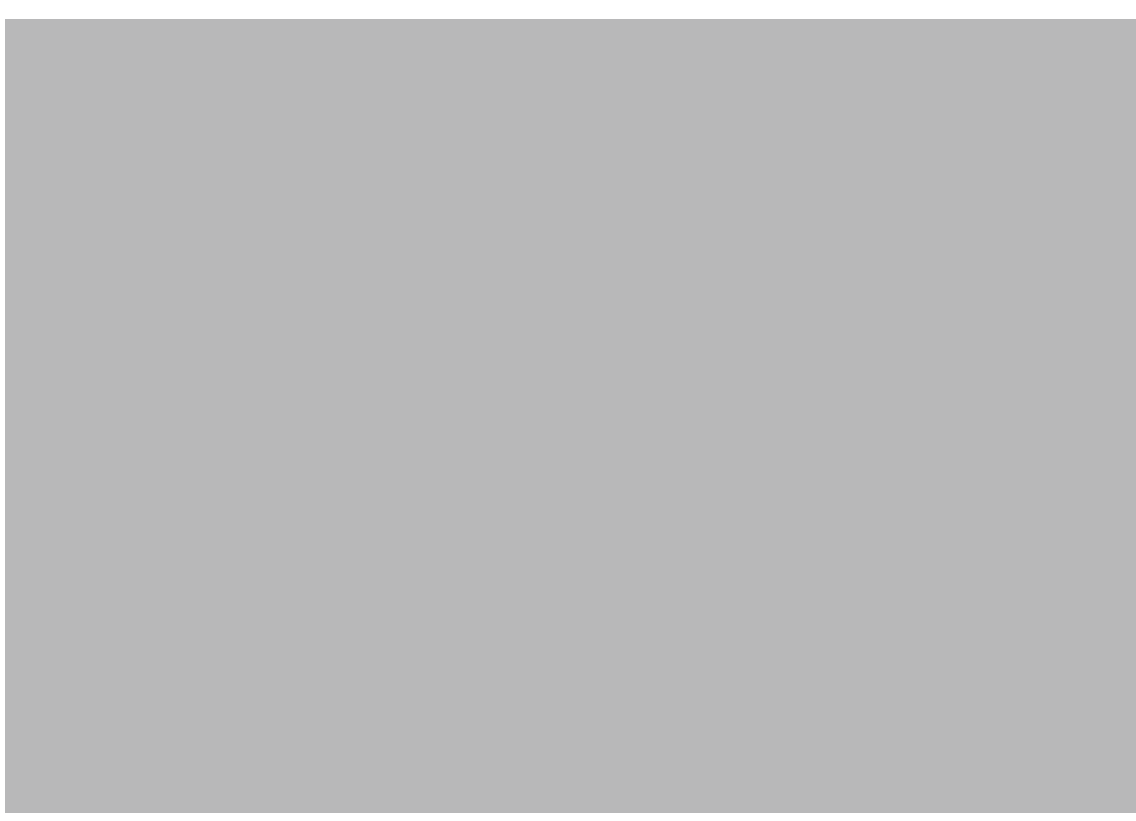

FIG. 5. VIIVIKONNA (EARLY 1950S) BY LENGIPROSHAKHT. FRONT: SHOP BUILDING. LEFT ONE-STOREYED RESIDENTIAL BUILDING. PHOTO: SIIM SULTSON (2018).

\section{RENOVATION (LATE 1960s TO 1980) TO DISSOLUTION}

On 28 July 1957, Chairman of Jõhvi District Executive Committee indicated that Viivikonna territory did not meet requirements for sanitary conditions (low peat land), and the settlement would not be subjected to further development (a new living district of the Viivikonna mine would be designed on another territory $)^{57}$. However, the town was renovated in the late 1960s to 1980. For example, the main building of the Viivikonna mine on the eastern border of the town was renovated and enlarged according to the 1966 reconstruction design of the State Planning Institute "Eesti Tööstusprojekt" in the late $1960 \mathrm{~s}^{58}$.

57 RA, ERA.R-3.3.3148, 16

58 RA, ERA.T-15.4-3.728.
On 18 October 1971, Chairman of Sillamäe Town Executive Committee sent a supplemented calculation of population (for period up to 2000) for designing a new master plan for Sillamäe to the Estonian SSR's State Committee of Construction and Architecture at the Estonian SSR's Council of Ministers. According to the calculation, "by 2000, the trust "Estonslanets" plans to resettle all inhabitants of settlement Viivikonna (1,130 people) to Sillamäe town.". ${ }^{59}$

Nevertheless, the streets, and infrastructure of the town (water supply, sewage, electricity etc) were renovated according to the 1974 to 1975 overhaul design of the Planning Institute "Kommunaalprojekt" in the mid-1970s ${ }^{60}$. Meanwhile, the planning institute compiled design overhauls for some residential and administrative buildings in Viivikonna in 1976-1980 ${ }^{61}$. Thus, Viivikonna was renovated for the period up to its dissolution in 2000.

\section{CONCLUSIONS}

Reduction of the Viivikonna territory was, first of all, caused by the aim to decrease the territory of all East Estonian oil-shale territory under the settlements from 5,000 ha to 3,300 ha in order to gain 1,700 ha for oil-shale mining, while increasing the overall population - e.g. in order to increase the economic efficiency and high productivity of the oil-shale area, housing had to be intensified by increasing the number of storeys. Meanwhile, the developments of 1950, regarding the master plan, its calculations with reference to the soil ("the very marshland", thick peat strata) were merely additional and yet conditional factors ${ }^{62}$ that became strengthened by the resolution of the USSR's Council of Ministers "On Decrease of Cost of Construction", passed on 9 May 1950. The resolution supported the need to decrease the territory under settlements through intensification of housing by increasing the number of storeys for houses. The resolution was followed by a survey of the GOSPLAN, which concerned the 1951

59 RA, ERA.R-1992.3.47, 3-7.

60 RA, ERA.T-2.4-1.10844

61 RA, ERA.T-2.4-1.11216; RA, ERA.T-2.4-1.2161; RA, ERA.T-2.4-1.12151.

62 For example, the 1951 official secret project sees "the very marshland" with the thick peat strata rather as an advantage; RA, ERA.R-1527.2.44, 47, 50. 
official secret project and was passed on 15 July $1950^{63}$. Both the previous trend (aim to decrease the territory), and the resolution with the survey formed a base for the letter of the Vice-Chairman of the Estonian SSR's Council of Ministers, written on 11 September 1950. Conclusion of the Expertise Bureau of the Department of Architecture of the Estonian SSR, passed on 5 July 1951, reflects that the territory of Viivikonna has decreased nearly twofold, while its population has, relatively, increased via intensification.

Thus, the aim to decrease territory under the settlements, plus better opportunities to establish surface mines, compared to the western territories of the oil-shale area, helped Viivikonna follow a pattern of compact and city-like housing stock, which consists of dominant apartment buildings and monumental public buildings that form functional and stately urban ensembles near the industrial complexes. The matter of the "very marshland", and having the thick peat strata and low peat land, referred to as anti-sanitary, just supported the pattern, established by the Department of Architecture of the Estonian SSR. Regardless of the indicated shortcomings, the town was renovated in the late 1960s to early 1980s within original and existent bounds - the activity that crystallised the pattern. As a result, Viivikonna is the only East Estonian oil-shale mining and industrial town that follows urban planning principles and a pattern established by the Department of Architecture of the Estonian SSR and has avoided remarkable enlargements. On the one hand, the stipulated dissolution for 2000 has set a certain time limit, on the other hand - it is time to make a balanced and well-argued decision on the fate of Viivikonna. It is a field of research for the state, local authorities, strategical planners, spatial planners, human geographers, and architects in tight cooperation with urban and architectural historians.
Silm Sultson: Vilvikonna - Formation of a Ghost Town Amongst Other East Estonian Oil-Shale Mining and INDUSTRIAL TOWNS

KeyWORds: EAst Estonia; OIL-Shale; industrial tOWNS; URBAN PLANNING; VIIVIKONNA; STALINISM

\section{SUMMARY}

The central Stalinist urban ensembles in East Estonian oil-shale mining and industrial towns Kohtla-Järve, Ahtme, Sompa, Jõhvi, Kukruse, Kiviõli, Kohtla-Nõmme and Sillamäe are protected by comprehensive plans and regarded as built-up areas of cultural and environmental value; Viivikonna, although similar to these towns, does not boast such patronage. Compared to other oil-shale mining and industrial towns, Viivikonna has become a brownfield nearly completely. What could be the reason for such a difference? Some answers may be found in history (1946-1980). Viivikonna is the only East Estonian oil-shale mining and industrial town that follows urban planning principles and a pattern, established by the Department of Architecture of the Estonian SSR, led by Harald Arman, to this day. However, it is necessary to decide the purpose of Viivikonna in the near future: whether parts or whole of the town are worthy of preservation - both in the economic and aesthetic sense.

\section{$\mathrm{CV}$}

Siim Sultson (b. 1972) holds a PhD in urban planning history and architectural history. He has worked as a lecturer and an associate professor of Art History since 2000. His field of research and research interests are Estonian twentieth-century interwar, postwar architecture, urban planning, and urban space; living space on the background of Soviet interwar and post-war urban planning; German interwar urban planning; and Stalinist urban ensembles in north-eastern Estonian cities: determination, typology, and potential as factors of the cities' spatial development. 
